
Maria BOȘTENARU DAN

Elemente artistice \& de sustenabilitate culturală în

proiectarea de arhitectură Artistic and cultural sustainability elements in architectural design

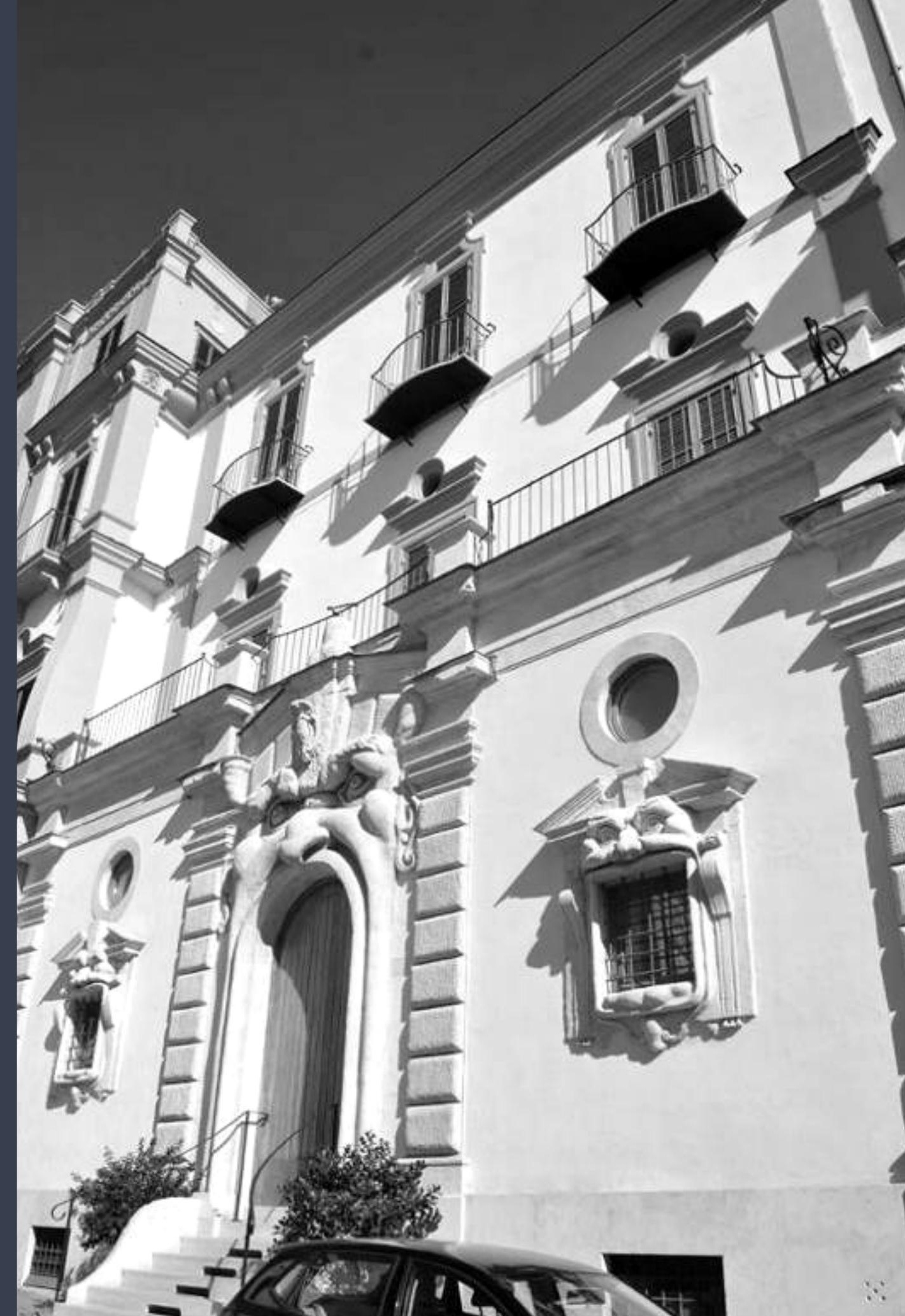




\section{Elemente artistice \& de sustenabilitate culturală în proiectarea de arhitectură}

\section{Artistic and cultural sustainability elements in architectural design}

rezumat.

Acest articol analizează academiile de artă din Roma, o caracteristică a orașului etern, începută în perioada redescoperirii Antichității în Renaștere și promovată ulterior de Grand Tour al lui Goethe. Am identificat 3 categorii: cele care urmează modelul coloniei de artiști, un model răspândit la fin de siecle, cele construite special în acest scop și cele care se găsesc în clădiri istorice, convertite. În afară de acestea trebuie remarcată unitatea Valle Giulia, inițial o expoziție universală, unde în locul pavilioanelor (cu excepția celui britanic) s-a urmat încă de acum 100 de ani tradiția internaționalității loturile făcând loc academiilor, finalizate până în perioada postbelică. O hartă story map realizată pentru acest articol vizualizează relația dintre poziția academiilor și geografia orașului, inclusiv unitățile coerente unde se găsesc acestea. cuvinte cheie

arhitectură, sustenabilitate culturală abstract

This article analyses the art academies in Rome, a characteristic of the eternal city, started in the time of the rediscovery of antiquity in the renaissance and promoted afterwards by the Grand Tour of Goethe. 3 types were identified: those which follow the model of an artist colony, a model spread at fin de siecle, those built specially for this purpose and those which are in historical, converted buildings. Apart of this the unity in Valle Giulia has to be remarked, initially an universal exhibition, where in place of the pavilions (with exception of the British one) already 100 years ago the tradition of internationality was followed, the parcels making place to academies, completed up to post-war time. A story map, designed for this article visualises the relationship between the position of the academies and the geography of the city, including the units where these are.

keywords

architecture, cultural sustainability

Fig. 1* Prezentarea Accademia di Romania în story map, Roma, Italia / Story map featuring Accademia di Romania, Rome, Italy

\section{Maria BOȘTENARU DAN}

maria.bostenaru@uauim.ro

Cercet. Dr.Arhitectură Ing.Arhitectură, DC*, UAUIM Researcher Dr.Architecture Eng.Architecture, DC*, UAUIM

*Departamentul pentru Cercetare (DC), UAUIM *Department for Research (DC), UAUIM

Departament Sinteza Proiectării de Arhitectură Facultatea de Arhitectură Universitatea de Arhitectură și Urbanism lon Mincu UAUIM București Synthesis of Architectural Design Department (SP) Faculty of Architecture Ion Mincu University of Architecture and Urbanism
UAUIM Bucharest

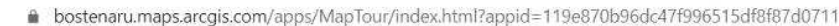

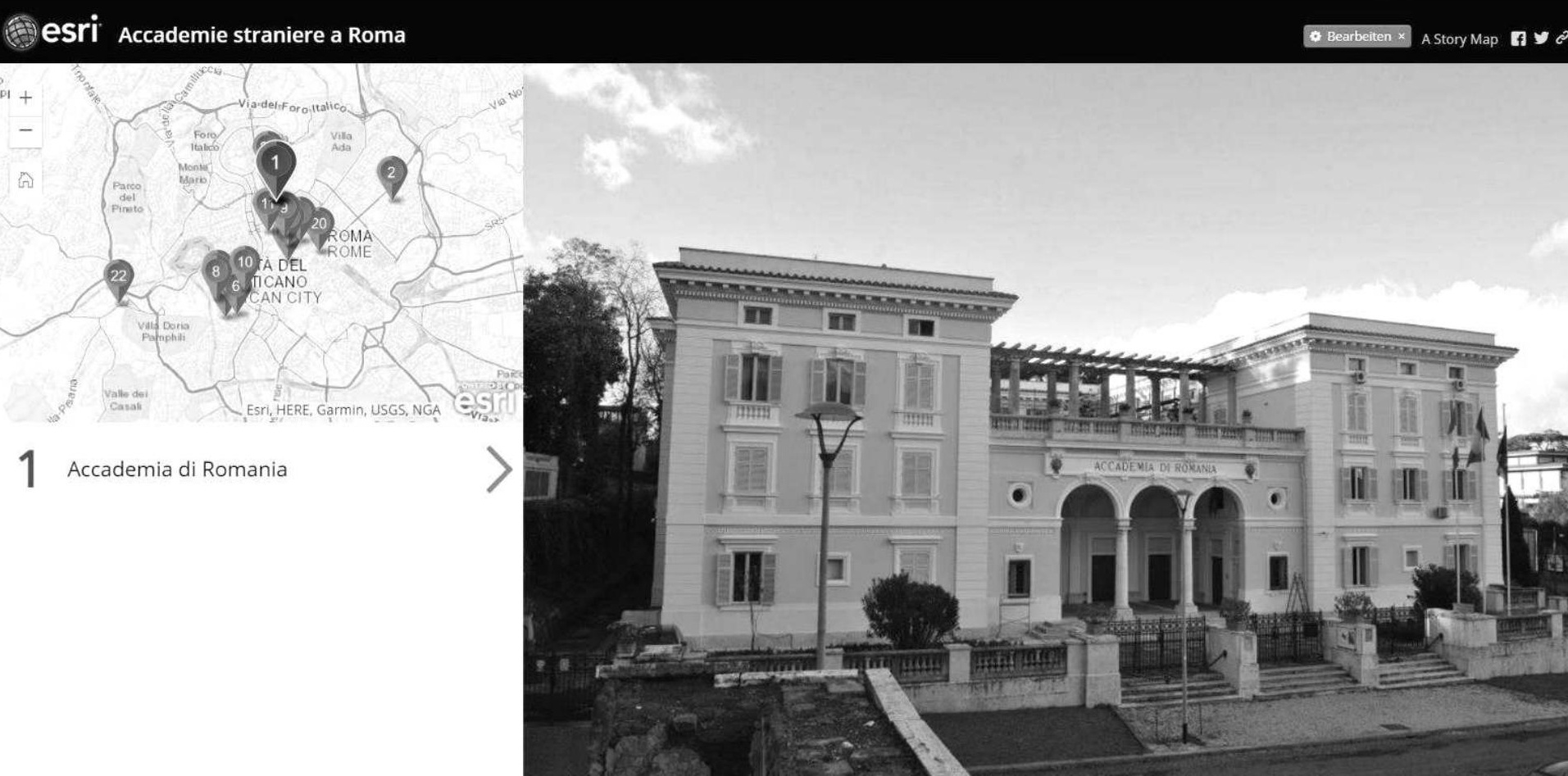


Vă invit să urmăm un parcurs în orașul Roma, la câteva dintre institutele străine și italiene din Roma: academii de artă și științe umaniste, pentru a vedea arhitectura acestora.

O listă completă a institutelor poate fi găsită aici: http://www.unioneinternazionale.it/istitutimembri/istituti-membri-non-italiani/ Unione Internazionale degli Istituti di Archaeologia, Storia e Storia dell'Arte in Roma, accesat 31.01.2020), cu mențiunea ca nu toate au putut fi incluse în această publicație, în ciuda efortului susținut.

Puteți accesa harta Story map pentru articolul: Elemente artistice \& de sustenabilitate culturală în proiectarea de arhitectură., de către autorul articolului: https://arcg.is/OHWPKP. (Fig.1)

Story map prezintă - ca parte din cercetare -, într-o hartă care poate fi mărită, locul exact din oraș unde se găsesc aceste instituții de creație și cercetare, în arte și științe umaniste (inclusiv arhitectură) în Roma, împreună cu o fotografie din exterior și descrierea fiecăreia. Descrierea modului în care clădirile satisfac cerințele acestui program de arhitectură se regăsește în rândurile următoare.

Unele din activitățile comune sunt plasate în luna internațională (în iunie), dar și conform Rome Art History Network - $\quad$ RAHN: https://www.romearthistorynetwork.com/ (accesat 31.01.2020), - precum și și direcționate de dialogurile Valle Giulia, întrucât multe au fost construite / transformate (funcțional și arhitectural) în Valle Giulia, precum se va vedea.
În analiza academiilor de artă (Mihaly, 2019), (True \& Varela Braga, 2018), am identificat - prin cercetare - 3 categorii: cele care urmează modelul coloniei de artiști, cu o vilă principală și ateliere în grădină (Franța, America, Germania - Pasquali, 2003), cele construite special pentru acest scop, și cele care se află în clădiri istorice, convertite funcțional. În plus, merită remarcată unitatea generării arealului valoros urban-arhitectural Valle Giulia, unde pe locul expoziției (Székely, 2009) s-a creat spațiul culturii universale (Garano, 2006), cu academii din diverse țări, tradiție căreia îi urmează luna culturii internaționale. Expoziția a avut loc cu ocazia a 50 de ani de la unificare și simultan cu cea din Torino.

Parcursul arhitectural prezintă date rezultate în urma cercetării urban-arhitecturale a arealului valoros Valle Giulia, bazate și pe consultarea materialelor open access, din online / web ale institutelor culturale ce funcționează în clădirile prezentate (în articol). Harta Story map permite direcționarea către paginile web dedicate, pentru întregirea imaginii funcțiunii culturale a arealului.

Imagini trimise pentru publicare sunt ale autorului articolului, Boștenaru Dan M.

Metodologia cercetării se leagă strâns de bursa postdoctorală Vasile Pârvan în arhitectură (Accademia di Romania, Roma, Italia) a autoarei, care a urmat bursei postdoctorale în geografie anterioare (Fac.Geografie, UB, Romania), și se referă la cartarea instituțiilor culturale ca parte a sustenabilității culturale. Autoarea a experimentat ca cercetator lucrul în institutele de artă comunicând cu artiști mai ales în cadrul expoziției Spazi Aperti (Accademia di Romania, Roma, Italia, 2016), în cadrul lunii culturi internaționale, dar și la alte evenimente în echipa de organizare (voluntariat), inclusiv Open House Roma, precum și consultând resursele / resursele digitale de bibliotecă și științe umaniste ale mai multor academii. Documentarea fotografică pe teren include atât parcursul interior cât și exterior, dar nu a putut fi inclusă în întregime în această prezentare. 
Accademia di Romania (Fig.2)

Inițiată în 1921 (legea din 22 oct. 1920), școala Română din Roma (Bărbulescu et al., 2013) a început să funcționeze în 1922. Lăzărescu (2002) documentează corespondenţa care a condus la ridicarea sediului şcolii. Ministrul Lahovary a dat sarcina de a construi noul sediu în Valle Giulia/ Villa Borghese la Roma, în vecinătatea unor academii străine (engleză, egipteană, suedeză, japoneză) sarcină revenită lui Petre Antonescu, care a și definitivat planul de construcţie pe 5 septembrie 1926, în perioada când era rector la Bucureşti. Piatra de temelie s-a pus pe 20 ianuarie 1928 în prezenţa lui Giulio Magni, consul, şi pe 16 ianuarie 1933 a fost inaugurată. Cuprindea o sală de conferinţe, filme, expoziţie, bibliotecă şi arhivă. Lucrarea a fost executată în beton şi zidărie. Iniţial concepută în stil neoromânesc, s-a cerut modificarea clădirii în cel greco-roman din cauza sitului, unde ar fi avut aspect de expoziţie internaţională, lucru efectuat. Clădirea se ridică pe locul fostului pavilion al Ungariei din cadrul Expoziției Mondiale din 1911.

Pe 26 și 27 octombrie 2012 a avut loc colocviul însoțit de expoziția documentară cu ocazia aniversării împlinirii a 90 de ani "Vasile Pârvan și Școala Română din Roma" cu lansarea volumului scris cu această ocazie (Bărbulescu et al., 2013).

\section{Germania - villa Massimo (Fig.3)}

A fost construită între 1910 și 1914 de Eduard Arnhold în cartierul Nomentano. În afara vilei propriu-zise există 10 ateliere amplasate adiacent.

\section{American Academy in Rome}

A fost fondată în 1913 din reuniurea American School of Architecture in Rome (1894) și American School of Classical Studies in Rome (1895). Sediul se află pe Gianicolo și include și Villa Aurelia. Are o 


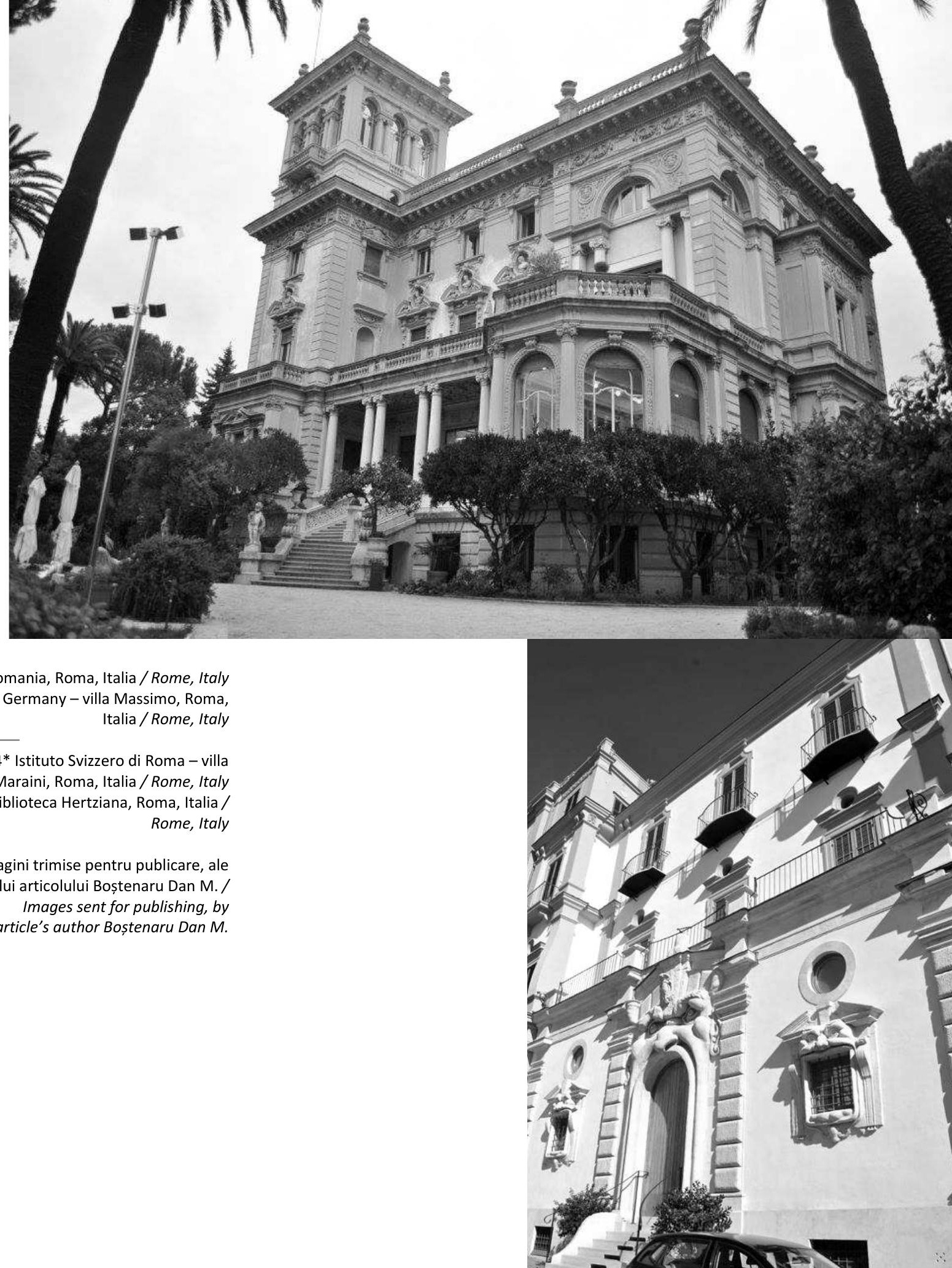




\section{Accademia d'Egitto}

După o idee din 1929, edificiul a fost construit între 1961 Ș। 1965. Între 2008 și 2010 clădirea a fost refăcută de designerul Hatem El Said și arhitectul Mohamed Abou Seada, cu o nouă stilistică de fațadă între antic și modern.

\section{Academia Belgica}

A fost înființată în 1939 când a fost și construit noul sediu.

\section{Koninklijk Nederlands Instituut Rome}

A fost fondată în 1904. Clădirea a fost proiectată de inginerul Italian Gino Cipriani și de arhitectul din Haga Jan Stuyt. Academia funcționează aici din 1933. Academia are și o grădină impresionantă, deschisă de ziua porților deschise din Olanda (17 iunie).

\section{Svenska Institutet i Rom}

Institutul a fost înființat în 1925 de regele Gustaf VI Adolf, care a avut expediții de arheologie la Roma. Clădirea Institutului de lângă grădina Borghese a fost construită în 1939 special în acest scop, proiectată de Ivar Tengbom. Acesta a fost un arhitect modernist, precum mai renumitul coleg Gunnar Asplund. Biroul este condus de urmașii acestuia.

\section{Accademia di Danimarca}

Academia, înființată în 1956, funcționează din 1967 în clădirea proiectată de Kay Fisker.

\section{British School at Rome (Fig.8)}

BSR a fost înființată în 1901. După Expoziția Internațională de Artă din Roma din 1911, pavilionul britanic proiectat de Edwin Lutyens a fost donat Marii Britanii în acest scop (singurul pavilion păstrat).
A fost adaptat în 1916 pentru această funcțiune. În 2002 a fost extins cu un amfiteatru și galerii de Hugh Petter.

\section{Forumo Austriaco di Cultura a Roma}

Edificiul s-a constituit printr-un acord italianoaustriac din 1935 constând în transformarea institutului istoric austriac, existent din 1881, întrunul de cultură (institut cultural). Edificiul este realizat din 1937.
Fig.6* Collegio Pio Romeno, Roma, Italia / Rome, Italy Fig.7 Villa Medici (Francia), Roma, Italia / Rome, Italy

Fig.8* British School at Rome, Roma, Italia / Rome, Italy Fig.9* Accademia San Luca, Roma, Italia / Rome, Italy * Imagini trimise pentru publicare, ale autorului articolului Boștenaru Dan M./ Images sent for publishing, by the article's author Boștenaru Dan M.

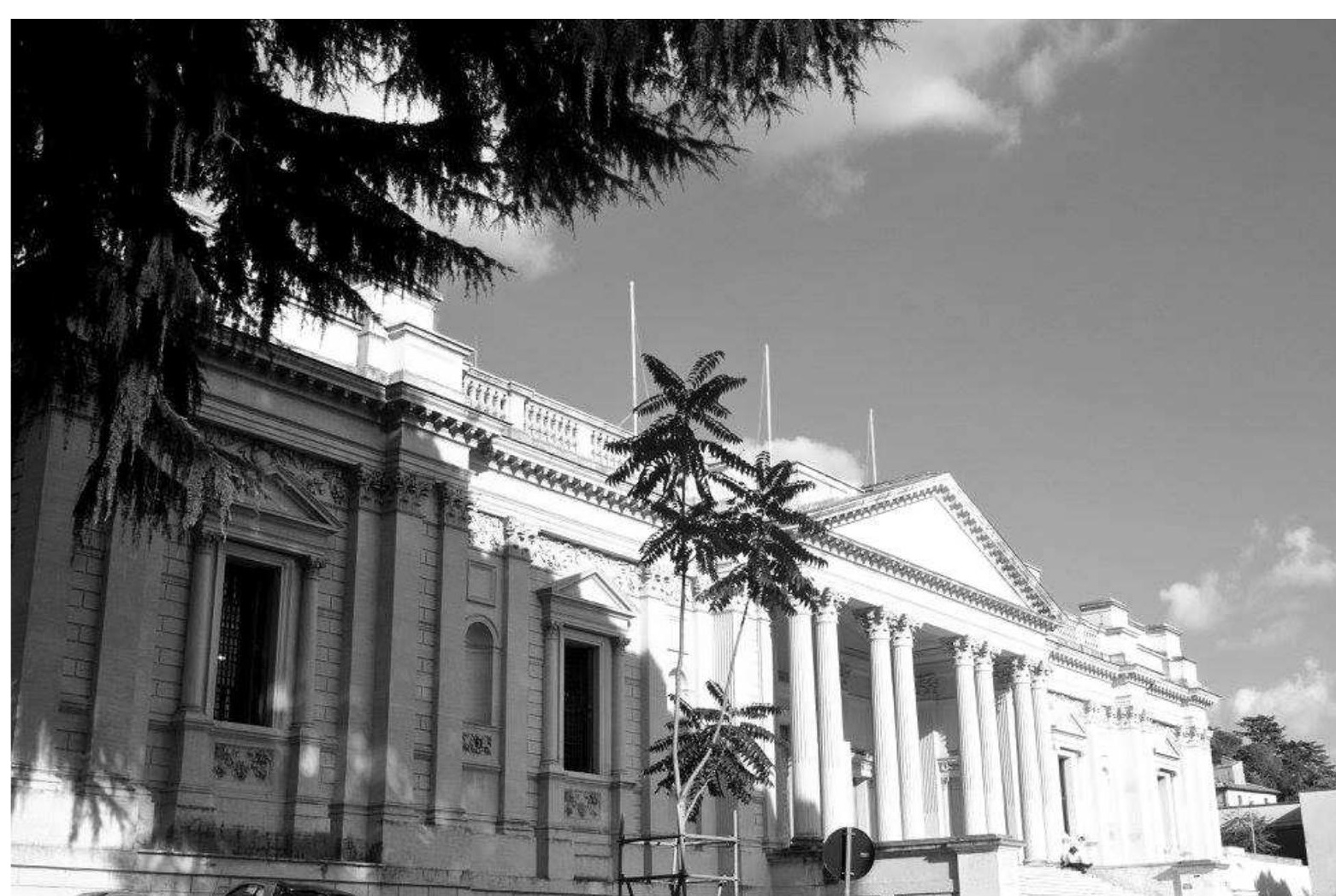


(english version)

I invite you to make a tour in the city of Rome to some of the foreign and Italian institutes in Rome: art and humanities academies, to see their architecture.

A complete list of all institutes can be found here: http://www.unioneinternazionale.it/istituti-

membri/istituti-membri-non-italiani/ (Unione

Internazionale degli Istituti di Archaeologia, Storia e Storia dell'Arte in Roma, accessed 31.01.2020), with the mention that not all of them are included in this overview, despite all efforts.

You can access Story Map for article: artistic and cultural sustainability elements in architectural design., by the article's author, at this link https://arcg.is/OHWPKP. (Fig.1)

The story map features - as a part of the research, in an enlargeable map, the exact location of the institutions for arts and humanities (including architecture) in Rome, together with an exterior image and description of each. The description of how the buildings meet the need of the architecture programme is described in the following lines.

Some of their common activities are placed in the international month (in June), but also according to the Rome Art History Network - RAHN https://www.romearthistorynetwork.com/ (accessed 31.01.2020), and also directed by the Valle Giulia dialogues, since many of them were built / transformed (functional and architectural) in Valle Giulia, as we will see.

In the analysis of art academies (Mihaly, 2019), (True \& Varela Braga, 2018), I identified - through research - 3 categories: those which follow the model oft he artist colonies with a main villa and workshops in the garden (France, USA, Germany Pasquali, 2003), those build especially for this purpose and those which are in functional converted historical buildings. Additionally, it has to be remarked the unit generation of urban-architectural valuable areal Valle Giulia, where on the place of the exhibition (Székely, 2009) the spaces of universal culture were created (Garano, 2006), with academies from different countries, tradition followed today by the month of international culture. The exhibition took place on occasion of 50 years of unity and simultaneously with that in Turin.

The architectural tour presents data resulted following the urban-architectural research of valle Giulia areal, based also on consulting open-access, online / web materials of cultural institutes functioning in presented buildings (in the article). Story map allows directioning towards web dedicated pages, for completing the cultural use image of the areal.

Images sent for publication belongs to the author of the article, Boștenaru Dan M.

The research methodology is closely related to the author's postdoctoral Vasile Pârvan fellowship in architecture (Accademia di Romania, Rome, Italy), which followed the previous postdoctoral fellowship in geography (Fac.Geografie, UB, Romania), and refers to the mapping of cultural institutions as part of cultural sustainability. The author has experienced as researcher working in art institutes, communicating with artists especially in the exhibition Spazi Aperti (Accademia di Romania, Rome, Italy, 2016), during the month of international culture, but also at other events in the organizing team (volunteering) including Open House Rome, as well as consulting the digital library and humanities resources / resources of several academies. Field photographic documentation includes both indoor and outdoor travel, but could not be fully included in this presentation. 


\section{Accademia di Romania (Fig.2)}

Initiated in 1921 (the law from 22nd of October 1920), the Romanian school in Rome (Bărbulescu et al., 2013) started to function in 1922. Lăzărescu (2002) documents the correspondence, which lead to raising the headquarters of the school. The minister Lahovary gave the task to built new headquarters in Valle Giulia/Villa Borghese next to other foreign academies (English, Egiptian, Swedish, Japanese) which was given to Petre Antonescu, who finished the construction plans on the 5th of September 1926, during the time when he was rector in Bucharest. The base stone was put on the 20th of January 1928 in the presence of Giulio Magni, consul, and on the 16th of January 1933 the construction opened. It contained a conference hall, for films as well, exhibition, library and archive. The building was built in concrete and masonry. Initially conceived in New Romanian style, it was requested to modify if to Greek-Roman because of the site, as it would have been an international exhibition look. The building was erected on the place of the Hungarian Pavilion from the 1911 International Exhibition.

On the 26th and 27th of October 2012 the conference accompanied by a documentary exibition "Vasile Pârvan and the Romanian School in Rome" took place with the launch of the volume written with this occasion (Bărbulescu et al., 2013).

\section{Germany - villa Massimo (Fig.3)}

The academy was built between 1910 and 1914 by Eduard Arnhold in the Nomentano neighbourhood. Apart of the villa there are 10 workshops nearby.

\section{American Academy in Rome}

It was founded 1913 through the junction of the American School of Architecture in Rome (1894) and American School of Classical Studies in Rome (1895). The headquarters are on the Gianicolo and include also Villa Aurelia. It has a considerable garden of 4,5 ha. The main building was designed by McKim, Mead and White in 1914.

In 2019 the Academy started an anniversary year of 125 years of existence, with various lectures (including at the opening of the university year at the Finnish Academy) but especially the conference

The Academy as a Mirror of Change: 125 Years of Arts and Humanities, on the 11th of November 2019, which is streamed on the Livestream page of the Academy

(https://livestream.com/aarome/events/8890671 accessed 11.03.2020).

Istituto Svizzero di Roma - villa Maraini (Fig.4)

It was founded in 1947. The headquarters are in villa Maraini, close to villa Borghese on Pincio. The building is in Art Nouveau style, built 1905 by Otto Maraini.

\section{Biblioteca Hertziana (Fig.5)}

It was founded 1913 by Henriette Hertz The headquarters are in Palazzo Zuccari. In 1963 Palazzo Stroganoff was added. In 2013 a new wing was built by the Spanish architect Juan Navarro Baldeweg. The new construction is not visible from outside, the historical facades were kept, but contributed also to the discovery in the basement of Antique ruins.

\section{Real Academia de España en Roma}

The headquarters are in the former monastery San Pietro in Montorio, built by Isabella di Castiglia and Ferdinand of Aragon, Catholic kings, between 1481 and 1500 on Gianicolo. The church of the monastery is further church (as functional use). Here was crucified, according to oral tradition, Saint Peter, and towards the church a scale with Cross Way is ascending. Well known is the Tempietto of Bramante (1510) built later in the courtyard of the monastery. 


\section{Collegio Pio Romeno (Fig.6)}

It is a higher education institution for Greek Catholic priests in Rome which was founded in 1937. It is situated on Gianicolo.

Institutum Romanum Finlandiae - Villa Lante a Gianicolo (Finlandia)

The villa was built between 1518 and 1531 by Giulio Romano. In 1551 it was taken over by the Lante family, from where it bears the name. These got for the garden which had to make place to the fortifications on Gianicolo the well known villa in Bagnaia. The Finnish state bought the building in 1950.

\section{Villa Medici (Francia) (Fig.7)}

Villa Medici is a villa in mannerist style built starting 1564-1574 by Nanni di Baccio Bigio and from 1568 by Annibale Lippi close to villa Borghese in Rome. From 1803, under Napoleon, it hosts Accademie de France, institution founded 1666 under Louis 14. The garden is on the place of the gardens of Lucullus in Antiquity.

\section{Palazzo Falconieri (Ungheria)}

It is the most valuable property of the Hungarian state abroad. The palace dates from the $16^{\text {th }}$ century, being extended by Francesco Borromini starting 1638 under the Mecenate of Orazio Falconieri. The Hungarian Academy was founded 1927 and has here the headquarters.

\section{Casa di Goethe}

It is the only German museum abroad, dedicated to Johann Wolfgang von Goethe and his journey in Italy. It is situated in the house where Goethe lived that time (1786-1788).

\section{Accademia d'Egitto}

Following an idea from 1929, the building was edificated between 1961 and 1965. Between 2008 and 2010 it was refurbished by the designer Hatem El Said and the architect Mohamed Abou Seada, with a new style manner for the facade, between Antique and Modern.

\section{Academia Belgica}

It was founded 1939 when also the new headquarters were built.

\section{Koninklijk Nederlands Instituut Rome}

It was founded in 1904. The building was designed by the Italian engineer Gino Cipriani and the architect from Hague Jan Stuyt. The Academy functions here since 1933. The Academy has also an impressive garden, open for the day of open doors in the Netherlands $\left(17^{\text {th }}\right.$ of June).

\section{Svenska Institutet i Rom}

The institute was founded 1925 by the king Gustaf VI Adolf, who had archaeology expeditions in Rome. The building of the institute near Borghese garden was built 1939 especially for this purpose, designed by Ivar Tengbom. The latter was a modernist architect, like the better known colleague Gunnar Asplund. The office is led by his heirs.

\section{Accademia di Danimarca}

The Academy, founded in 1956, functions since 1967 in the building designed by Kay Fisker.

\section{British School at Rome (Fig.8)}

BSR was founded in 1901. After the International Arts Exhibition in Rome in 1911, the British pavilion designed by Edwin Lutyens was donated to GB in this scope (the only remaining pavilion). It was adapted 
1916 for this function. In 2002 it was extended with an amphitheatre and galleries by Hugh Petter.

\section{Forumo Austriaco di Cultura a Roma}

The building was edificated based on an ItaloAustrian agreement in 1935, through the conversion of the Austrian Historical Institute (present in Rome since 1881) in one of culture (institute of culture). The building dates from 1937.

\section{Accademia San Luca (Fig.9)}

It was founded 1577 by an artists' association. Through the focus on teaching and public exhibitions, Accademia di San Luca became a model for the modern academies. The headquarters are in Palazzo Carpegna from the $17^{\text {th }}$ century, designed by the Baroque architect Pietro da Cortona, with a facade towards the forum. The building also displays an art gallery.

\section{Santa Susanna}

It is a Cistercian monastery, founded in 1587, close to the Therme of Diocletian in Rome. In this place there was one of the oldest paleochristian churches in Rome. The church became this Baroque shape 1590-1603 by the architects Domenico Fontana and Carlo Maderno (the latter designed the facade, similar to II Gesu, the first Baroque church). This is the place where the scholars of the Romanian Academy were before the dedicated building was built.

\section{Istituto Giapponese di Cultura Roma}

Ken Nakajima (1914-2000) designed the garden of the Japanese Cultural Institute in Rome. In this garden the tea pavilion has a special interpretation, being the building of the institute itself, in concrete which resembles timber. The garden uses the natural slope of the terrain in Valle Giulia.

\section{Deutsches Historisches Institut Rom}

Founded 1888, it is one of the oldest German Historical Institutes abroad, founded after the opening of the archives of Vatican.

\section{Referințe / References}

Bărbulescu, M., Damian, I. M., Turcus, V. (2013). Accademia di Romania din Roma, Accad. di Romania, Roma. 1912-2012

Bostenaru Dan M. (2019). Story Map for Article: artistic and cultural sustainability elements in architectural design. https://arcg.is/OHWPKP (accesat / accessed 27.09.2019)

Garano, S. (ed.) (2006). Valle Giulia 1911-2011: la valle delle accademie tra storia e progetto. Palombi Editori.

Lăzărescu, G. (2002). Şcoala Română din Roma, Editura Fundaţiei Culturale Române.

Mihaly, R. (2019). La costruzione identitaria di un'élite culturale, Nuova cultura.

Pasquali, M. (2003). I giardini della diplomazia. Ambasciate accademie straniere a Roma. Electa - Mondadori.

Székely, M. (2009). Magyar müvészet a világ kiállításokon 18961918 között, PhD Thesis, Eötvös Loránd Tudományegyetem, Budapest.

True, T., Varela Braga, A. (eds.) (2018). Roma e gli artisti stranieri. Integrazione, reti e identità (XVI-XX s.), Artemide.

Windholz, A. (2008). ET IN ACADEMIA EGO Ausländische Akademien in Rom zwischen künstlerischer Standortbestimmung und nationaler Repräsentation 1750 - 1914, Schnell + Steiner.

Citare articol curent / Citation

(Ro)

Boștenaru Dan M. (2021). Elemente artistice \& de sustenabilitate culturală în proiectarea de arhitectură. în Teoria proiectului de arhitectură. Idei construite. SP FA UAUIM. EUIM Editura Universitară Ion Mincu, București.

(En)

Bostenaru Dan M. (2021). Artistic and cultural sustainability elements in architectural design. in Architectural design theory. Built ideas. SP FA UAUIM. EUIM - Ion Mincu University Publishing House, Bucharest. 


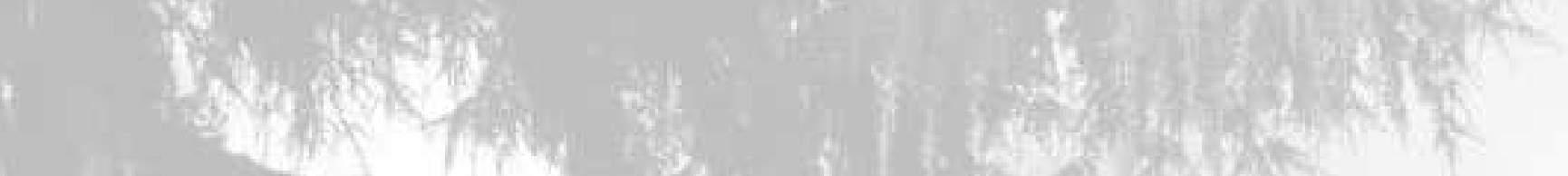

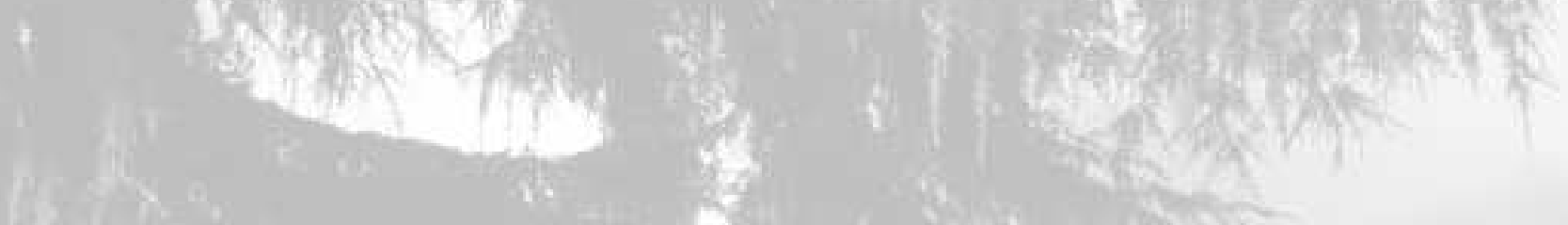

(3)

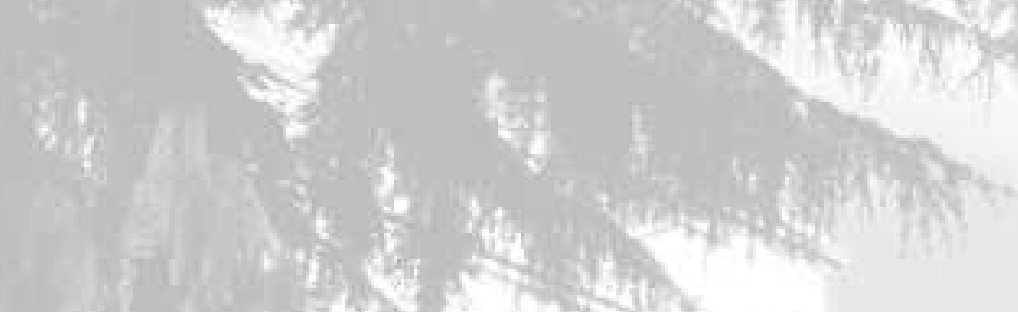

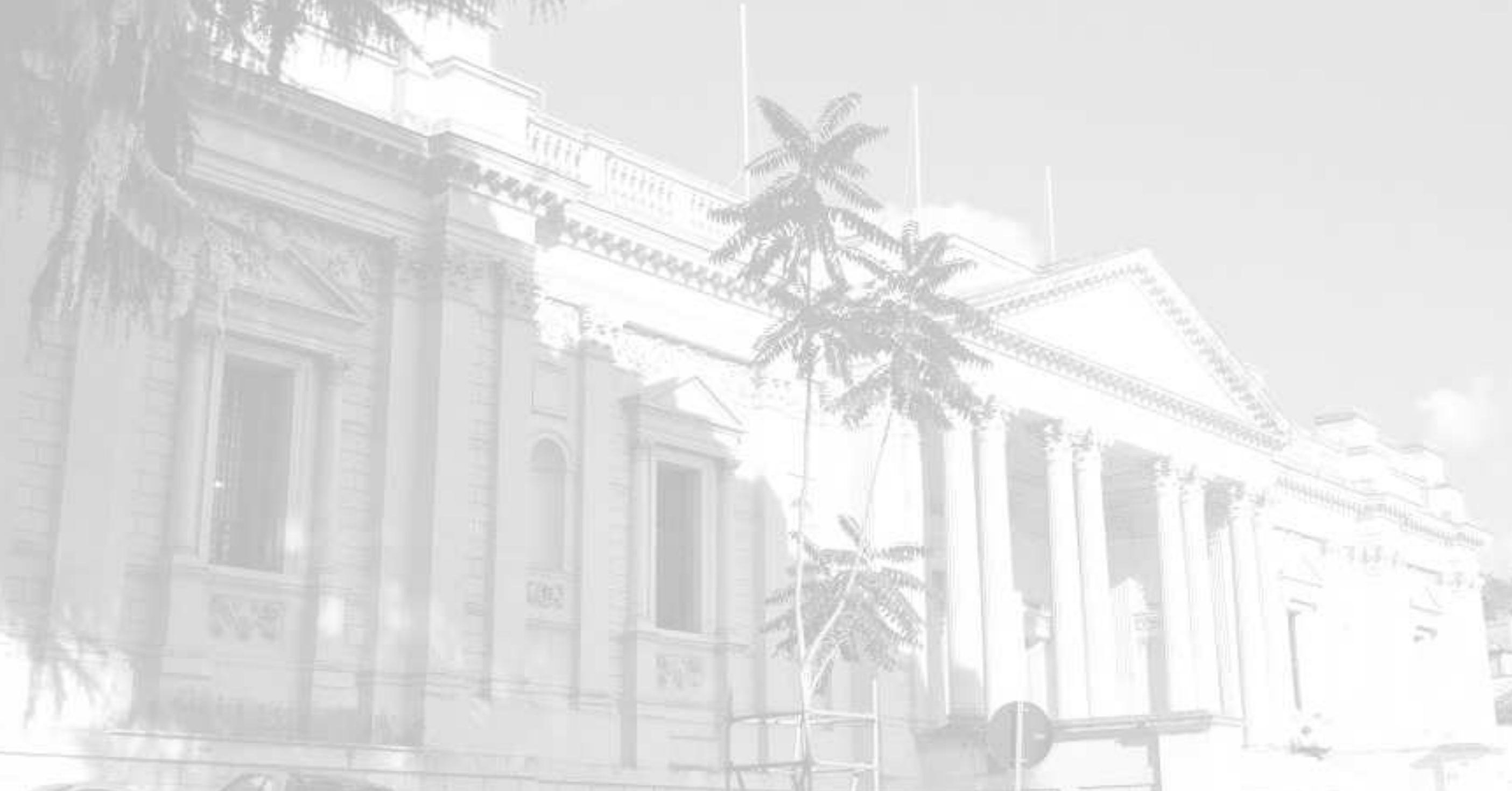

